International Journal of Engineering \& Technology, $7(2.8)(2018) 603-611$
International Journal of Engineering \& Technology
SPC
Website: ww.sciencepubco.com/index.php/IJET
Research Paper

\title{
Reduction of SSR oscillations in power system network with STATCOM and UPFC
}

\author{
J. Sreeranganayakulu' ${ }^{1}$ G.V. Marutheswar ${ }^{2}$, P.Sujatha ${ }^{3}$ \\ ${ }^{1}$ Research Scholar, Dept. of EEE, JNTUA, Ananthapuramu, A.P., INDIA \\ ${ }^{2}$ Professor EEE Dept., S V University, Tirupati, A.P., INDIA \\ ${ }^{3}$ Professor, Dept.of EEE, JNTUA CEA, Anantapuramu, A.P., INDIA
}

\begin{abstract}
SSR is a complex issue in electric power transmission network because of which the mechanical arrangement of a multi mass model encounters shaft harms. To keep away from this issue the mechanical oscillations which for the most part happen amid a balanced short circuit fault on the transmission network ought to be moderated by a few means. This paper delineates about the IEEE second benchmark framework which is demonstrated and simulated in MATLAB Simulink. The outcomes are compared when Static Synchronous Compensator (STATCOM) is incorporated and furthermore with those when Unified Power Flow Controller (UPFC) included for their viability in moderating the Subsynchronous Resonance motions.
\end{abstract}

Keywords: Flexible AC Transmission Systems, SSR, STATCOM, UPFC.

\section{Preface}

In present electric power system networks, sub synchronous resonance (SSR) is a serious problem which makes the system unstable in the event of faults due to the presence of series capacitors. Due to this phenomenon, the shaft mechanism undergoes undamped oscillations which may cause total shaft failure. As per theory, it happens, when the electric network transfers energy with a turbine generator at one or more of the regular frequencies of the connected network beneath the system frequency[1].

To analyze the problem of SSR, some standard test cases were prepared by the IEEE SSR task force [2-3]. In this model, six masses coupled to the same shaft namely 'High Pressure', 'Intermediate Pressure', 'Low Pressure A', 'Low Pressure B', 'Generator' and 'Exciter'. These are interconnected with transmission network viz. a 600 MVA, 22/500 kV transformer. This model is developed in MATLAB and is simulated for analysis [3].

For minimizing the SSR oscillations, FACTS like STATCOM and UPFC can be included in parallel with the series capacitor.

V-I characteristic for a STATCOM is like that of a synchronous condenser, yet it has no inertia and is profitable in different perspectives over the synchronous condenser, for example, better dynamics, a low speculation cost and diminished working and maintenance costs. Control analyses for systems [10-19].

A STATCOM is comprised of Thyristors with great turn-off capability such as GTO or an Insulated Gate Controlled Thyristor or with large number of IGBTs. STATCOM has a merit that the variation of reactive power is independent of the real voltage at the supply. This aspect is viewed in the figure 1 where the maximum currents flowing are independent of the voltage in contrast with the SVC.

This implies, that amid most severe fault conditions, the STATCOM works with full capability.
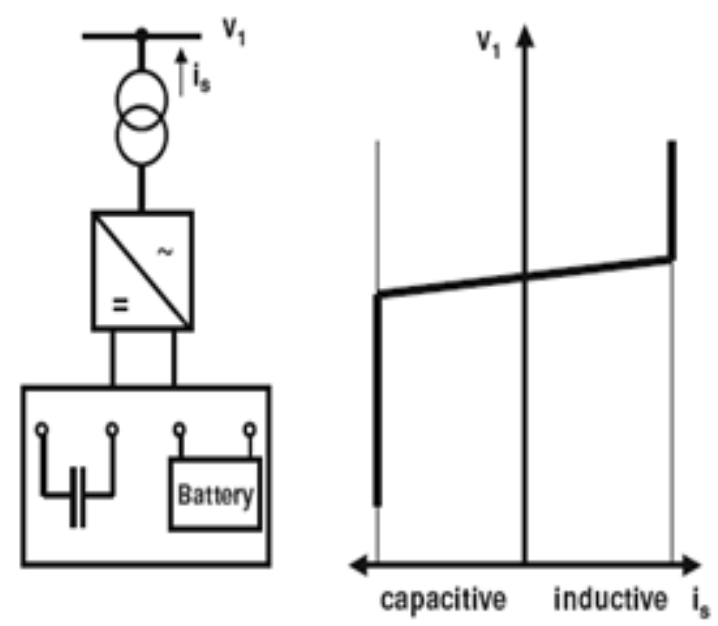

Fig. 1: Structure of STATCOM and voltage / current characteristic

\section{Principle of Operation of STATCOM}

Fig. 2 shows a three phase six pulse STATCOM. Here, in the event that voltage of STATCOM 'Vs' is more in contrast with bus voltage, 'Es', at that point capacitive or leading VArs are generated and if 'Vs' is lesser than 'Es' then inductive or lagging VArs are generated. 


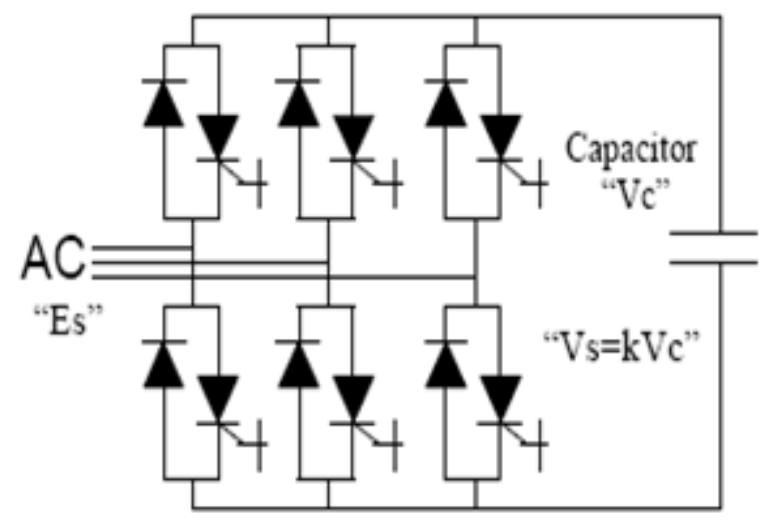

Fig. 2: STATCOM with Three Phase six pulse

The STATCOM shown in Fig. 2 operates according to the principle that, for a three phase power system network operating at system frequency in steady state, the average power flowing into a pure reactive component should become nullified at any instant.

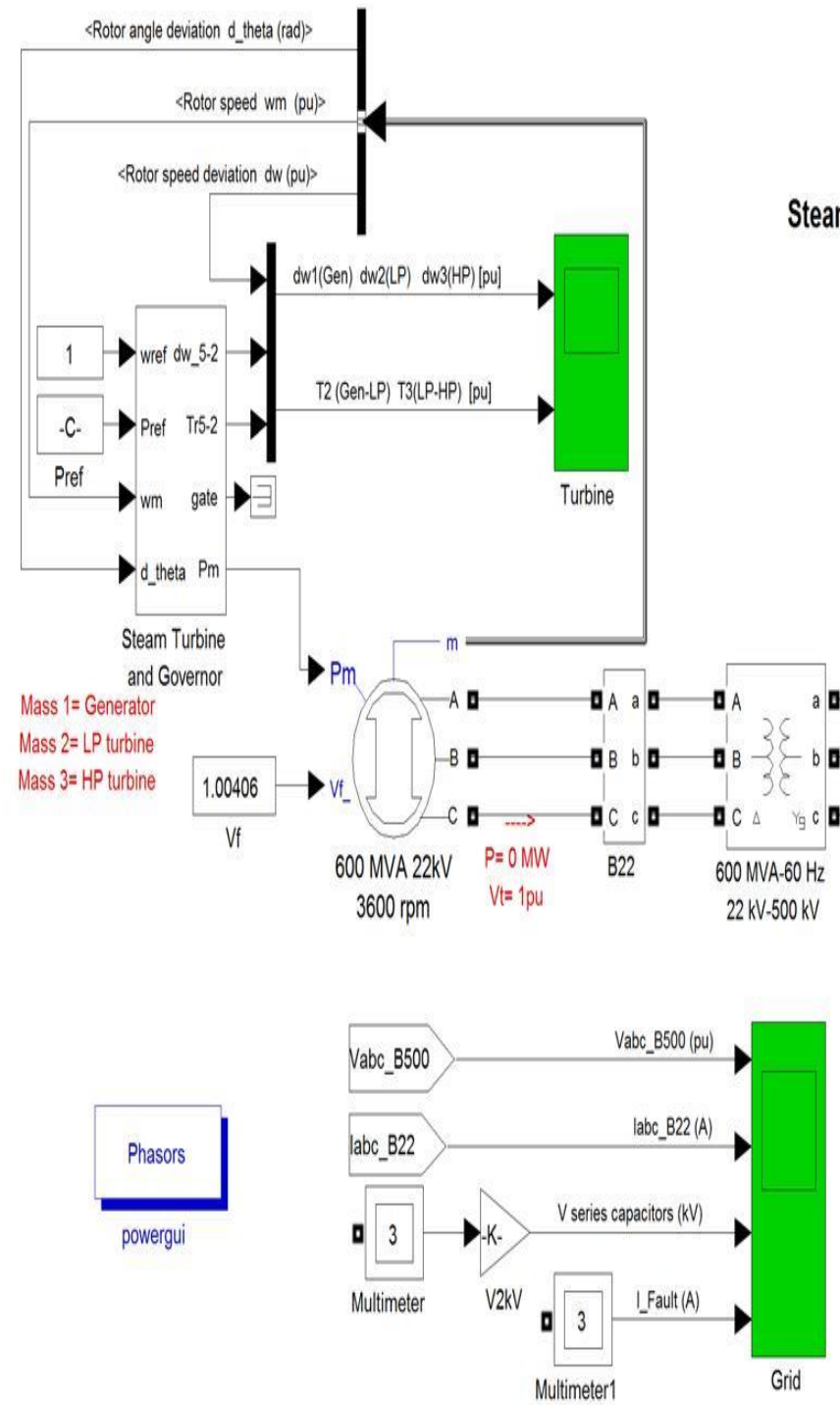

In present case, each phase receives VArs which can be generated at every instant by circulating the real power between the phases which is instantaneous. To achieve this, proper firing of the Gate Turn Off/diode switches should be done in such a way so as to maintain the difference in phase angles of bus voltage 'Es' and 'Vs' at every instant.

Based on circulating instantaneous power criteria, a device can be built without any energy storage element.

Figure 3 shows a MATLAB Simulink model similar to the IEEE Second benchmark system is first developed including the STATCOM across the series capacitor used for compensation [4]. The results after simulation are shown in Fig. 4. From the figure, it seems that the Subsynchronous Resonance oscillations between Low Pressure - High Pressure turbines are reduced gradually and are limited less than 1 p.u. Observing the graph it can be seen that with addition of STATCOM the Subsynchronous Resonance currents are lessened and so the torque oscillations are restricted to lie within limits.

team Turbine and Governor System - Subsynchronous Resonance
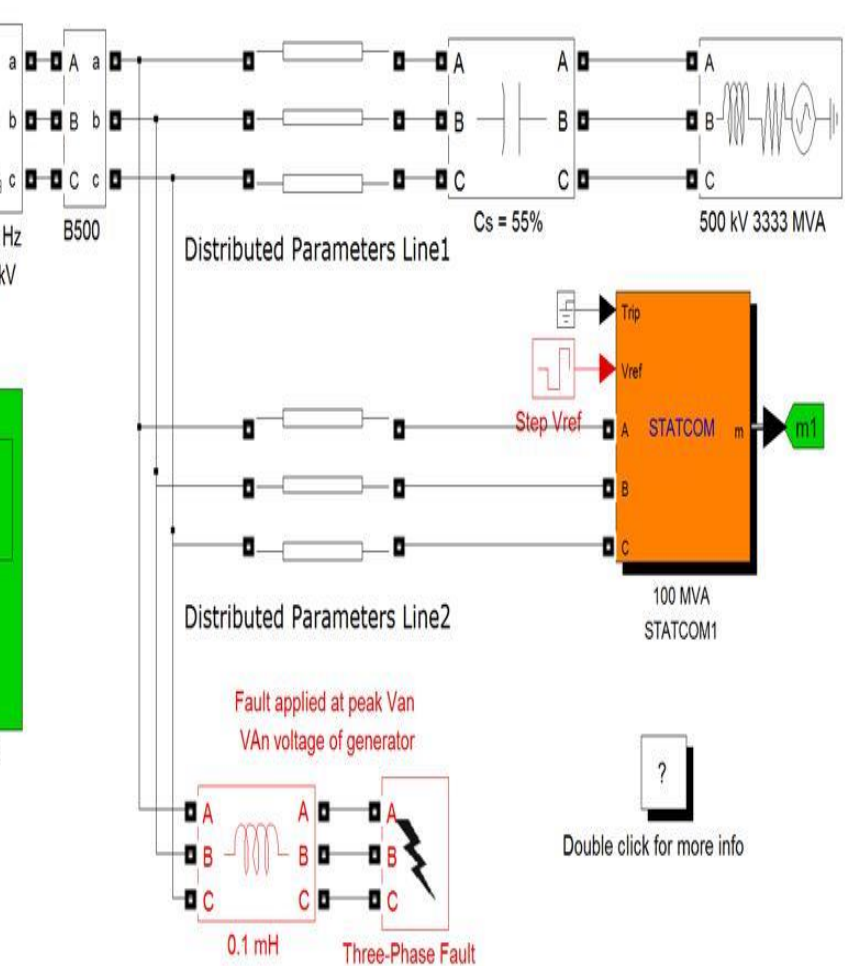

Fig. 3: Simulation circuit for the IEEE SBM system with STATCOM 

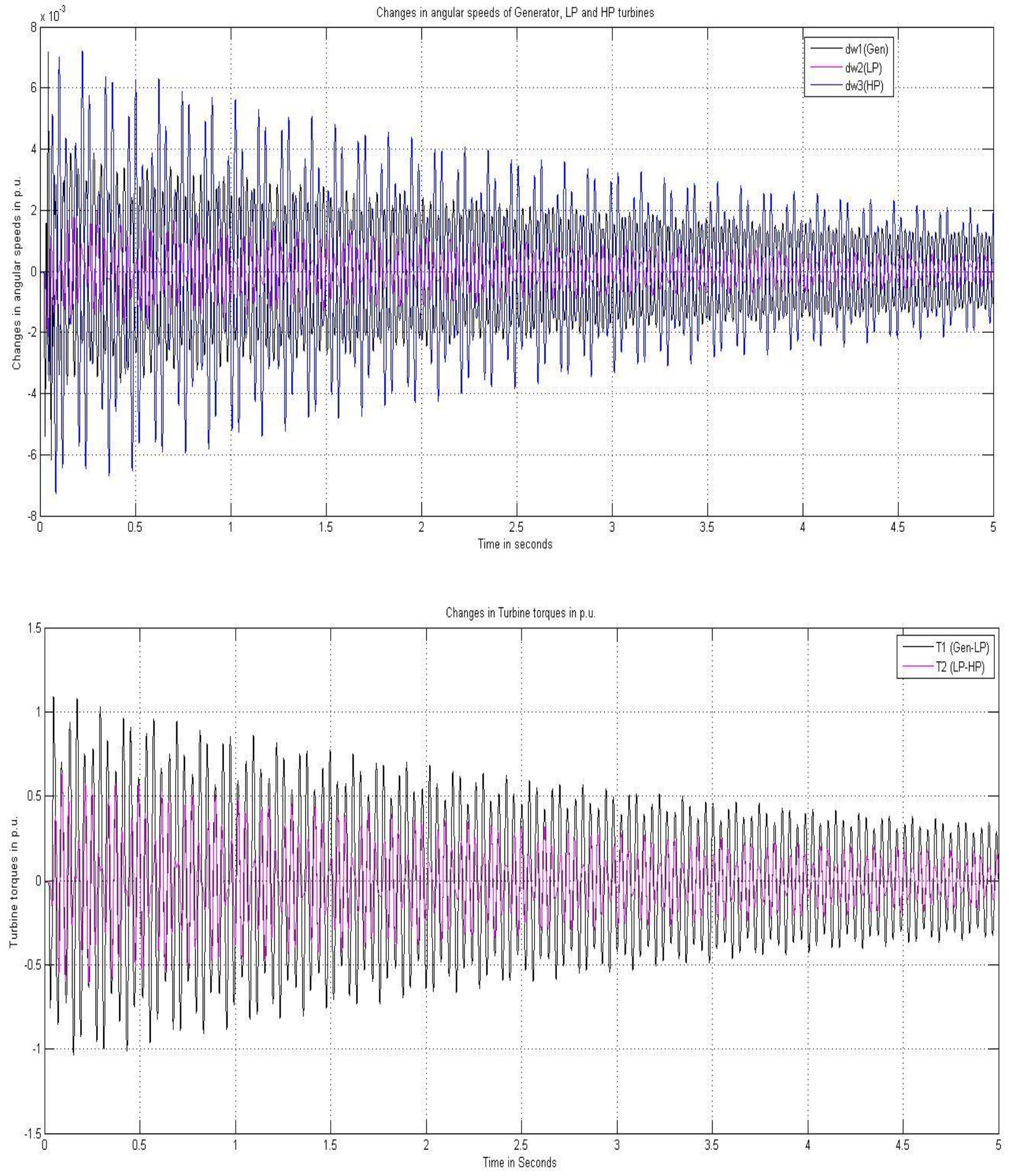

Fig. 4: Gen, LP, HP turbine outputs with respect to time with STATCOM 

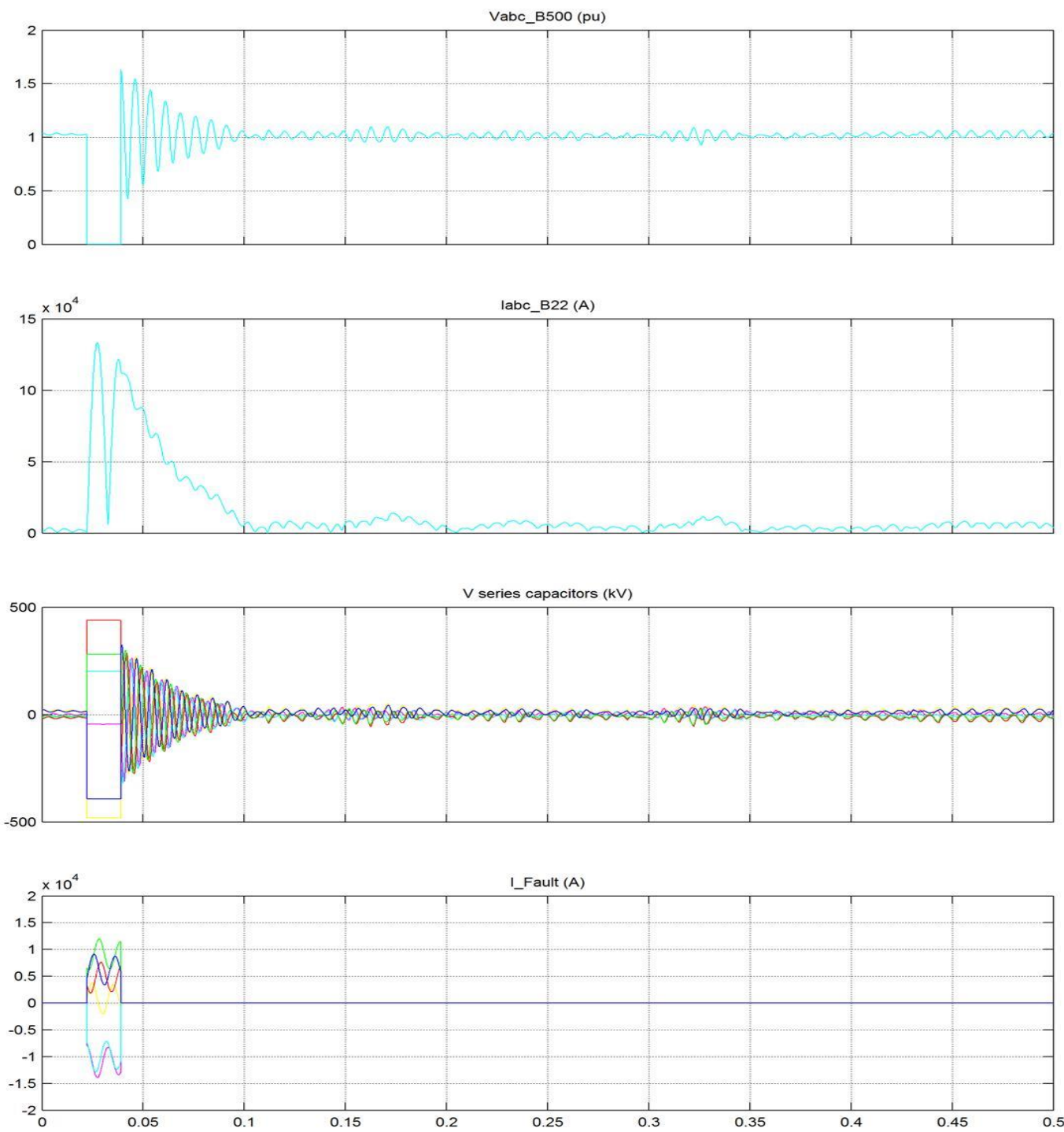

Time offset: 0

Fig. 5: $V_{L}($ p.u. $), I_{L}(A), V_{C}$ and fault current wave forms with respect time with STATCOM

A basic UPFC is made up of shunt transformer and series transformer. These transformers are linked through two VSCs having a typical DC link capacitor. Exchange of real power between shunt transformer and series transformers is allowed in the DC circuit to control phase angle shift of the series voltage.

The basic UPFC arrangement is as shown in figure 6. It gives the full controllability for voltage and power flow. A thyristor bridge is used to protect the series converter.

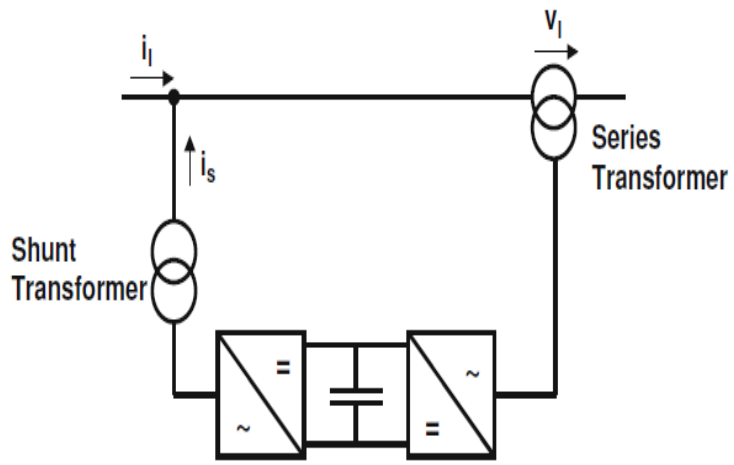

Fig. 6: UPFC basic configuration

\section{Operating Principle of UPFC}

An UPFC has basic components such as two voltage source inverters that share a common dc storage capacitor. These are connected to the power system network via coupling transformers. One of the voltage source inverters is linked to in shunt to the power transmission network through a shunt transformer, while the other VSI is linked in series through a series transformer. Fig.7 shows a basic Unified Power Flow Controller functional scheme.

\section{UPFC}

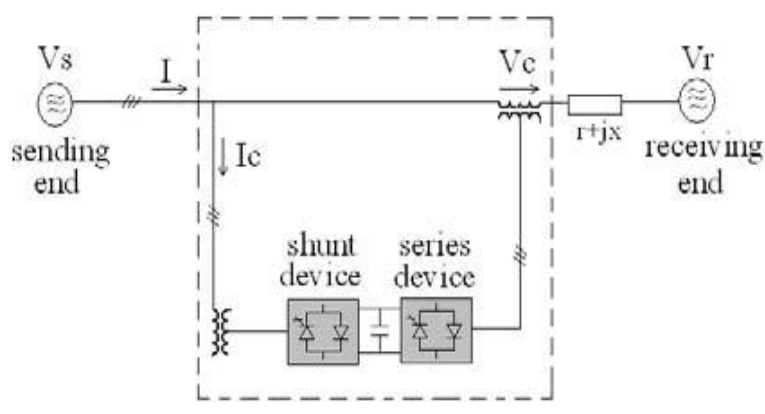

Fig. 7: Functional scheme of a basic UPFC 
Fig. 8 depicts the inclusion of UPFC in place of STATCOM to test the performance of the network during transient condition [10]. The simulation results given in figures 9 and 10 shows that UPFC gives more improved performance in reducing of the torque pulsations and angular speed deviations as well as improvement in voltage profiles.

\section{Results}

The results after MATLAB simulation are given in Table I. It gives a comparison about the reduction in maximum amplitudes of torque pulsations and the changes in angular speeds of various masses without inclusion of FACTS controllers where the SSR oscillations are uncontrolled.

Then the same results are compared including STATCOM and UPFC. Here, from the table, it is clear that the effectiveness in damping SSR oscillations is more as the magnitudes of oscillations are lessened to a smaller value with inclusion of UPFC in contrast to STATCOM.

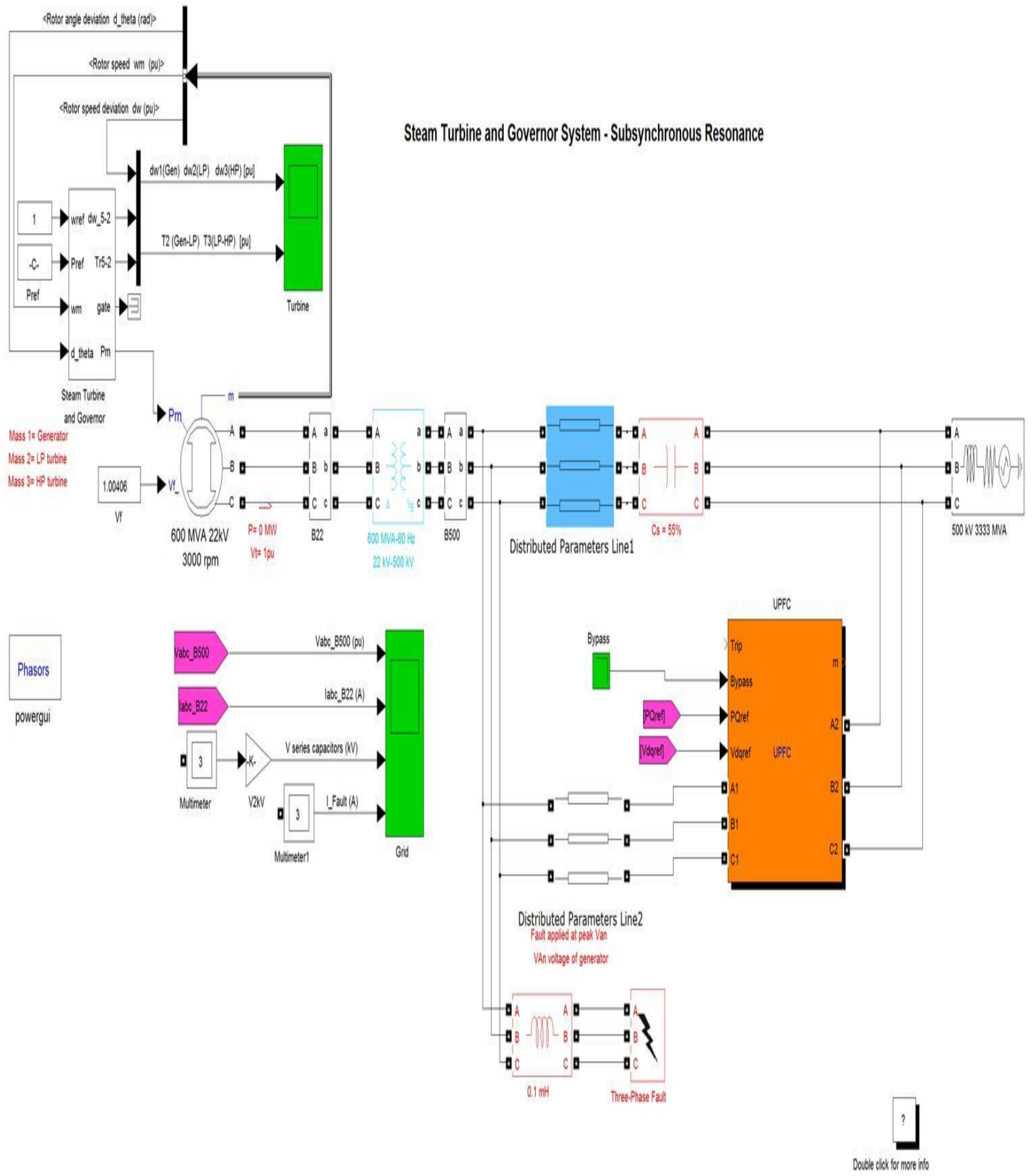

Fig. 8: MATLAB model for the IEEE SBM system with Unified Power Flow Controller (UPFC) 

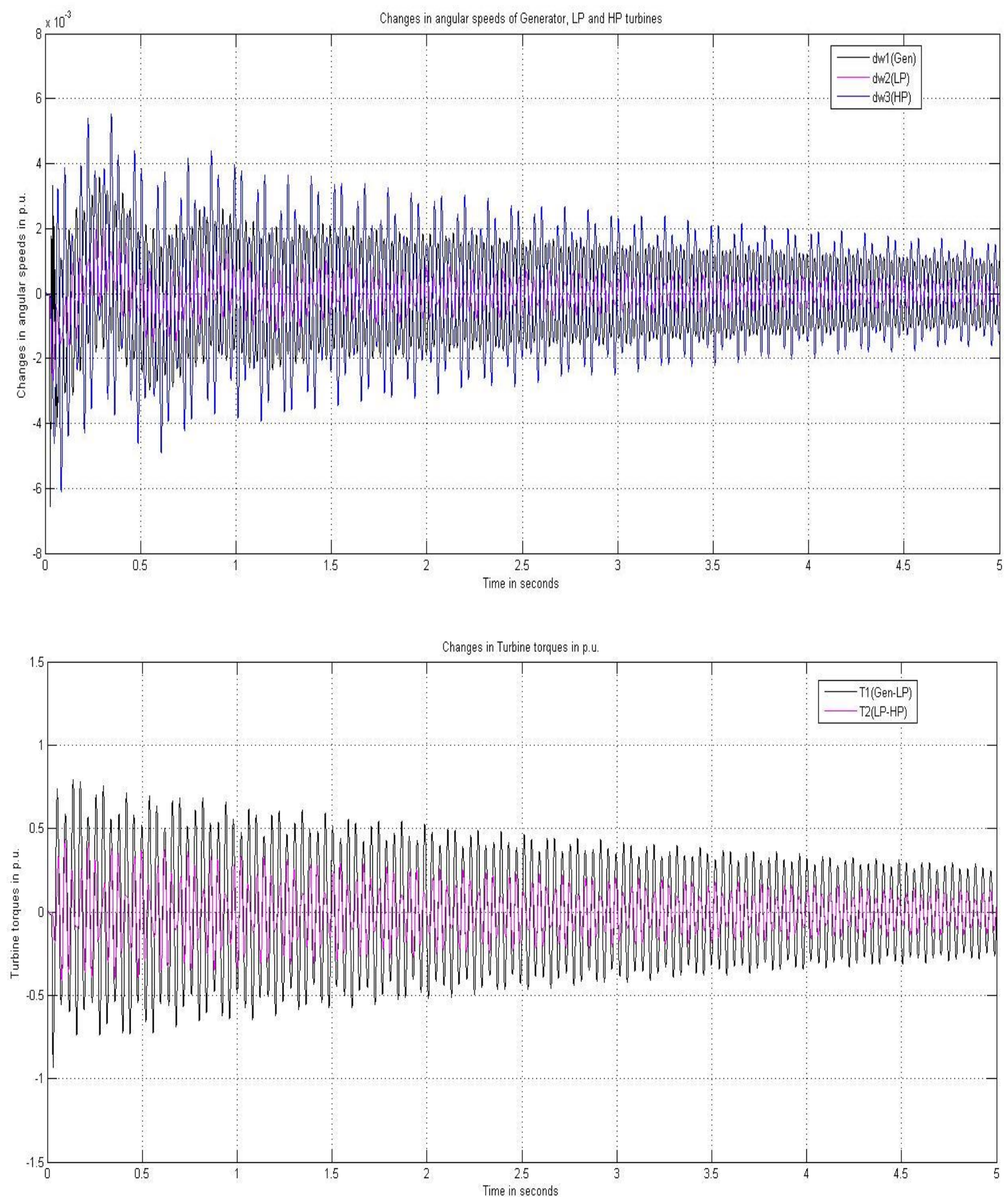

Fig. 9: Gen, LP, HP turbine outputs with respect to time with Unified Power Flow Controller 

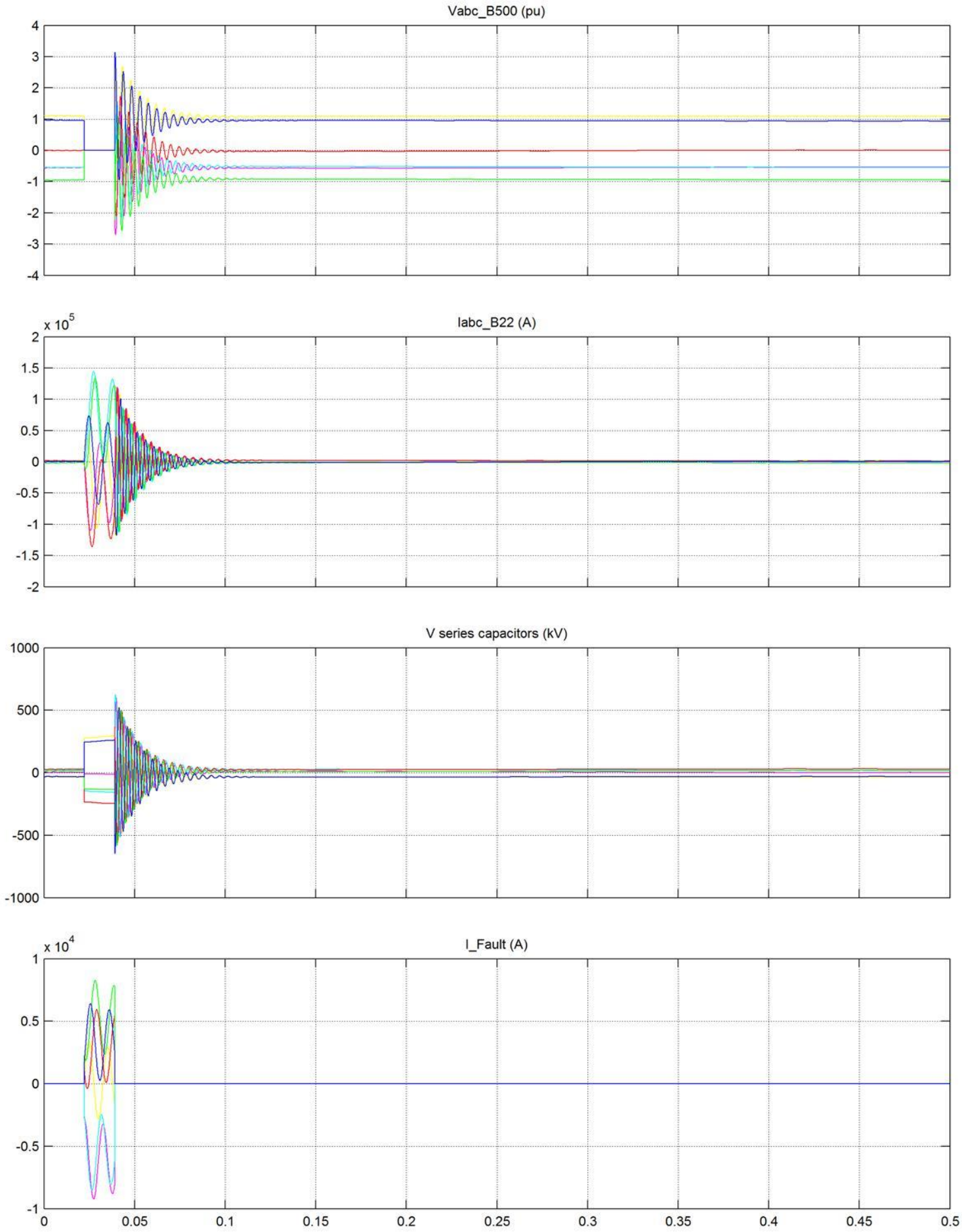

Time offset: 0

Fig. 10: $V_{L}$ (p.u.), $I_{L}(A), V_{C}$ and fault current wave forms with respect time with Unified Power Flow Controller Table I. Torque Pulsation Magnitudes And Angular Speed Deviations For The Three Cases 


\begin{tabular}{|c|c|c|c|c|c|c|c|c|c|c|}
\hline \multirow[t]{2}{*}{ Case } & \multicolumn{2}{|c|}{$\begin{array}{c}\text { Generaor - Low } \\
\text { Pressure Torque (p.u.) }\end{array}$} & \multicolumn{2}{|c|}{$\begin{array}{c}\text { Low Pressure-High } \\
\text { Pressure Torque (p.u.) }\end{array}$} & \multicolumn{2}{|c|}{ d $\omega$ (Generator) p.u. } & \multicolumn{2}{|c|}{ d $\omega$ (Low Pressure) pu } & \multicolumn{2}{|c|}{ d $\omega$ (High Pressure) pu } \\
\hline & Minimum & Maximum & Minimum & Maximum & Minimum & Maximum & Minimum & Maximum & Minimum & Maximim \\
\hline $\begin{array}{c}\text { With no } \\
\text { FACTS } \\
\text { device } \\
\end{array}$ & -2.4 & 2.5 & -1.1 & 1.15 & -0.012 & 0.0097 & -0.0072 & 0.0058 & -0.0145 & 0.0145 \\
\hline $\begin{array}{c}\text { With } \\
\text { inclusion of } \\
\text { STATCOM }\end{array}$ & -1.035 & 1.07 & -0.58 & 0.652 & -0.0061 & 0.00715 & -0.0025 & 0.002 & -0.0074 & 0.0072 \\
\hline $\begin{array}{l}\text { With } \\
\text { UPFC }\end{array}$ & -0.937 & $0 I 8$ & -0.4 & 0.42 & -0.0067 & 0.0038 & -0.0023 & 0.00208 & -0.0061 & 0.0056 \\
\hline
\end{tabular}

\section{Conclusions}

In this paper, an effort is made to illustrate the comparison in effectiveness of UPFC and STATCOM in mitigating the SSR oscillations that are present in the power system network during transients. Three cases are examined to study the turbine torques variations and angular speeds changes:

1. With no FACTS controller.

2. When STATCOM is included and

3 . When UPFC is included.

The results given in section IV clearly indicates how the UPFC can reduce the torque pulsations between various shafts of the multi mass model, as well as changes in angular speeds in generator, low pressure and high pressure turbines more effectively than STATCOM. Improvement in the power system network is noticed with inclusion of UPFC rather than STATCOM. But there is a need for compromise between the economy and network performance as UPFC is costlier when compared to STATCOM.

\section{Appendix}

\section{Parameters of AC system:}

Voltage of transmission: 500 kilovolts

Supply frequency: $50 \mathrm{~Hz}$

(a) Transmission lines Parameters (3 ph):

R per km: $0.02 \Omega$,

L per km: 0.9 Henry

$\mathrm{C}$ per km: $13 \mu \mathrm{F}$,

Transmission Line length: $200 \mathrm{~km}$

$\mathrm{X}_{\mathrm{C}}: 30$ percent of $\mathrm{X}_{\mathrm{L}}$

\section{(b) Alternator details:}

Rated Power: 600MVA

Line to Line voltage: $22 \mathrm{kV}$

Reactances: $\mathrm{Xd}=1.65, \mathrm{Xd}^{\prime}=0.25, \mathrm{Xd}{ }^{\prime \prime}=0.2, \mathrm{Xq}=1.59, \mathrm{Xq}{ }^{\prime}=$

$0.46, \mathrm{Xq}$ " $=0.2$

Time Constants:

Tdo' $=4.5 \mathrm{sec}$, Tdo' $=0.04 \mathrm{sec}$,

Tqo' $=0.67 \mathrm{sec}$, Tqo' $=0.09 \mathrm{sec}$

Resistance of stator $=0.0045 \mathrm{pu}$

(c) Power Transformer Details:

Nominal Power: 600 Mega volt amperes (3 ph)

Voltage rating: $22 \mathrm{kV} / 500 \mathrm{kV}$ (Line-Line)

\section{References}

[1] IEEE SSR working group, "proposed terms and definitions for sub synchronous resonance," IEEE symposium on countermeasures for sub synchronous resonance, IEEE Pub.81TH0, p086-9 PWR,1981 p 92-97.

[2] IEEE SSR working group,'First benchmark model for computer simulation of sub synchronous resonance". IEEE transactions on power apparatus and systems, vol. PAS-96, pp. 15651572,September/october 1977.
[3] IEEE SSR working group,"Second benchmark model for computer simulation of sub synchronous resonance ". IEEE transactions on power apparatus and systems, vol. PAS-104, pp. 1057-1066,may 1985.

[4] Dr. Narendra Kumar, Sanjiv Kumar and Vipin Jain, "Damping Sub synchronous Oscillations In power system using shunt and series connected FACTS controllers", IEEE transactions on power delivery, vol.2, Sep 2010.

[5] P.M. Anderson, B.L. Agrawal, J.E. Van Ness, "Sub synchronous Resonance in Power Systems", IEEE Press, New York, 1990, pp.31-93.

[6] N.G. Hingorani \& L. Gyugyi, "Understanding of FACTS", IEEE Press

[7] J.Guo, M.L.Crow, J.Sarangapani "An improved UPFC Control for Oscillation Damping" IEEE Transactions on Power Systems, Vol. 24,No. 1, Feb. 2009,pp.288-296.

[8] J.Sreeranganayakulu, N.Chinna Alluraiah, "Simulation of first benchmark model for analysis of sub synchronous resonance in power systems using SEQUEL”, IJERA ISSN: 2248-9622, Dec 2011

[9] J.Sreeranganayakulu, Dr.G.V.Marutheswar, Dr.K.S.R Anjaneyulu, "Mitigation of Subsynchronous Resonance oscillations using UPFC", Global Journal of Trends in Engineering, Vol.2, Issue.3, March 2015.

[10] R. Kalaivani, K. Ramash Kumar, S. Jeevananthan, "Implementation of VSBSMC plus PDIC for Fundamental Positive Output Super Lift-Luo Converter,” Journal of Electrical Engineering, Vol. 16, Edition: 4, 2016, pp. 243-258.

[11] K. Ramash Kumar,'Implementation of Sliding Mode Controller plus Proportional Integral Controller for Negative Output Elementary Boost Converter," Alexandria Engineering Journa (Elsevier), 2016, Vol. 55, No. 2, pp. 1429-1445.

[12] P. Sivakumar, V. Rajasekaran, K. Ramash Kumar, "Investigation of Intelligent Controllers for Varibale Speeed PFC Buck-Boos Rectifier Fed BLDC Motor Drive," Journal of Electrical Engineering (Romania), Vol.17, No.4, 2017, pp. 459-471.

[13] K. Ramash Kumar, D.Kalyankumar, DR.V.Kirbakaran” An Hybrid Multi level Inverter Based DSTATCOM Control, Majles Journal of Electrical Engineering, Vol. 5. No. 2, pp. 17-22, June 2011, ISSN: 0000-0388.

[14] K. Ramash Kumar, S. Jeevananthan, "A Sliding Mode Control for Positive Output Elementary Luo Converter," Journal of Electrical Engineering, Volume 10/4, December 2010, pp. 115 127.

[15] K. Ramash Kumar, Dr.S. Jeevananthan," Design of a Hybrid Posicast Control for a DC-DC Boost Converter Operated in Continuous Conduction Mode" (IEEE-conference PROCEEDINGS OF ICETECT 2011), pp-240-248, 978-1-42447925-2/11.

[16] K. Ramash Kumar, Dr. S. Jeevananthan," Design of Sliding Mode Control for Negative Output Elementary Super Lift Luo Converter Operated in Continuous Conduction Mode", (IEEE conference Proceeding of ICCCCT-2010), pp. 138-148, 978-14244-7768-5/10.

[17] K. Ramash Kumar, S. Jeevananthan, S. Ramamurthy” Improved Performance of the Positive Output Elementary Split InductorType Boost Converter using Sliding Mode Controller plus Fuzzy Logic Controller, WSEAS TRANSACTIONS on SYSTEMS and CONTROL, Volume 9, 2014, pp. 215-228.

[18] N. Arunkumar, T.S. Sivakumaran, K. Ramash Kumar, S. Saranya, "Reduced Order Linear Quadratic Regulator plus Proportional Double Integral Based Controller for a Positive 
Output Elementary Super Lift Luo-Converter," JOURNAL OF THEORETICAL AND APPLIED INFORMATION TECHNOLOGY, July 2014. Vol. 65 No.3, pp. 890-901.

[19] Arunkumar, T.S. Sivakumaran, K. Ramash Kumar, "Improved Performance of Linear Quadratic Regulator plus Fuzzy Logic Controller for Positive Output Super Lift Luo-Converter," Journal of Electrical Engineering, Vol. 16, Edition:3, 2016, pp. 397-408.

[20] S.V.Manikanthan and V.Rama“Optimal Performance of Key Predistribution Protocol In Wireless Sensor Networks" International Innovative Research Journal of Engineering and Technology ,ISSN NO: 2456-1983,Vol-2,Issue -Special -March 2017.

[21] T. Padmapriya and V. Saminadan, "Inter-cell Load Balancing Technique for Multi- class Traffic in MIMO - LTE - A Networks", International Conference on Advanced Computer Science and Information Technology, Singapore, vol.3, no.8, July 2015. 